\title{
Novel Multiplex and Loop-Mediated Isothermal Amplification Assays for Rapid Species and Mating-Type Identification of Oculimacula acuformis and O. yallundae (Causal Agents of Cereal Eyespot), and Application for Detection of Ascospore Dispersal and In Planta Use
}

\author{
Kevin M. King, ${ }^{1,2, \dagger}$ Gavin J. Eyres, ${ }^{2}$ Jonathan S. West, ${ }^{1}$ Clara Siraf, ${ }^{1}$ Pavel Matusinsky, 3,4 Jana Palicová, ${ }^{5}$ \\ Gail G. M. Canning, ${ }^{1}$ Geoff L. Bateman, ${ }^{1}$ Bart A. Fraaije, ${ }^{1,6}$ and Paul S. Dyer ${ }^{2}$ \\ ${ }^{1}$ Rothamsted Research, Department of Biointeractions and Crop Protection, Harpenden, Hertfordshire AL5 2JQ, United Kingdom \\ ${ }^{2}$ School of Life Sciences, University of Nottingham, University Park, Nottingham NG7 2RD, United Kingdom \\ ${ }^{3}$ Department of Botany, Faculty of Science, Palacky University Olomouc, 77900 Olomouc, Czech Republic \\ ${ }^{4}$ Agrotest fyto, Ltd., 76701 Kromeriz, Czech Republic \\ ${ }^{5}$ Crop Research Institute, 16106 Prague 6-Ruzyně, Czech Republic \\ ${ }^{6}$ NIAB, Cambridge, CB3 OLE, United Kingdom \\ Accepted for publication 1 August 2020.
}

\begin{abstract}
Eyespot, caused by the related fungal pathogens Oculimacula acuformis and $O$. yallundae, is an important cereal stem-base disease in temperate parts of the world. Both species are dispersed mainly by splashdispersed conidia but are also known to undergo sexual reproduction, yielding apothecia containing ascospores. Field diagnosis of eyespot can be challenging, with other pathogens causing similar symptoms, which complicates eyespot management strategies. Differences between $O$. acuformis and $O$. yallundae (e.g., host pathogenicity and fungicide sensitivity) require that both be targeted for effective disease management. Here, we develop and apply two molecular methods for speciesspecific and mating-type (MAT1-1 or MAT1-2) discrimination of $O$. acuformis and $O$. yallundae isolates. First, a multiplex PCR-based diagnostic assay targeting the MAT idiomorph region was developed, allowing simultaneous determination of both species and mating type. This multiplex PCR assay was successfully applied to type a global collection of
\end{abstract}

ABSTRACT isolates. Second, the development of loop-mediated isothermal amplification (LAMP) assays targeting $\beta$-tubulin sequences, which allow fast ( $<9 \mathrm{~min}$ ) species-specific discrimination of global $O$. acuformis and $O$. yallundae isolates, is described. The LAMP assay can detect very small amounts of target DNA (1 pg) and was successfully applied in planta. In addition, mating-type-specific LAMP assays were also developed for rapid $(<12 \mathrm{~min})$ genotyping of $O$. acuformis and $O$. yallundae isolates. Finally, the multiplex PCR-based diagnostic was applied, in conjunction with spore trapping in field experiments, to provide evidence of the wind dispersal of ascospores from a diseased crop. The results indicate an important role of the sexual cycle in the dispersal of eyespot.

Keywords: disease control and pest management, mycology, population biology, techniques
Eyespot ("strawbreaker") is an important component of the stembase disease complex of cereals, including wheat (Triticum aestivum), barley (Hordeum vulgare), and rye (Secale cereale), in temperate parts of the world including Europe, the U.S. Pacific Northwest, and New Zealand (Lucas et al. 2000). The disease appears as eye-shaped lesions on stems, potentially causing stem weakening and lodging and associated economic losses (Fitt 1992).

${ }^{\dagger}$ Corresponding author: K. M. King; kevin.king@rothamsted.ac.uk

Funding: Work by K.M.K., J.S.W., C.S., G.G.M.C., and B.A.F. was funded by the Agriculture and Horticulture Development Board (project 21120002-2140021) and the Biotechnology and Biological Sciences Research Council's Industrial Strategy Challenge Fund, Smart Crop Protection strategic programme (BBS/OS/CP/ 000001). Work by G.J.E., G.L.B., and P.S.D. was funded by the Lawes Agricultural Trust and Department for Environment, Food and Rural Affairs. G.J.E. also thanks the Cheshire Police Force for financial support. Work by J.P. and P.M. was funded by the Ministry of Agriculture of the Czech Republic (MZE-RO0418, MZERO1118) and IGA-Prf-2021-001.

K. M. King and G. J. Eyres contributed equally to this work.

*The $\boldsymbol{e}$-Xtra logo stands for "electronic extra" and indicates that three supplementary figures are published online.

The author(s) declare no conflict of interest.

Modified: 18 Oct 2021.

(C) 2021 The American Phytopathological Society
Recently, the species responsible for cereal eyespot have undergone nomenclatural revisions. Currently, two related species in the genus Oculimacula are recognized, namely Oculimacula acuformis (formerly Tapesia acuformis, Pseudocercosporella herpotrichoides var. acuformis, R-type) and Oculimacula yallundae (formerly Tapesia yallundae, Pseudocercosporella herpotrichoides var. herpotrichoides, W-type) (Crous et al. 2003; Lucas et al. 2000). For clarity, O. acuformis and $O$. yallundae will be used throughout this article, even when referring to historical publications that use the former names (Bierman et al. 2002). The two pathogens co-occur in many cereal-growing regions of the world (Lucas et al. 2000). Evidence from Parnell et al. (2008) indicates that the relative abundance of the two species has changed on multiple occasions from 1986 to 2000 in Western Europe, possibly as a result of differential fungicide selection.

Distinguishing between $O$. acuformis and $O$. yallundae can help guide mitigation strategies for eyespot control because there are key biological differences between the species. First, there are differences in host pathogenicity, with $O$. yallundae being more pathogenic on wheat than on barley and causing only slight disease symptoms on rye, whereas $O$. acuformis is almost equally pathogenic on all these crop species (Hollins et al. 1985; Lucas et al. 2000). However, it should be noted there are also likely to be individual differences in aggressiveness between isolates of both species (Ray et al. 2006). Second, there are also possible differences relating to host resistance; for example, Burt et al. (2010) reported 
that in wheat seedling bioassays Pchl-mediated resistance was highly effective against both $O$. acuformis and $O$. yallundae, whereas $P$ ch2-mediated resistance was more effective against $O$. acuformis than $O$. yallundae. Third, there are epidemiological differences between the species, attributed mostly to different rates of development after host infection; for example, faster-developing O. yallundae is often found earlier in crops (Bateman and Jenkyn 2001; Goulds and Fitt 1991). Last, there are differences in fungicide sensitivity between the species; for example, O. acuformis appears intrinsically less sensitive to triazoles than $O$. yallundae, but both $O$. acuformis and $O$. yallundae are sensitive to prochloraz (Leroux and Gredt 1997). Thus, as reviewed in detail by Lucas et al. (2015), the relative frequencies of the two species have changed a number of times in pathogen populations under selection by different fungicide treatments.

Eyespot management strategies must target both $O$. acuformis and O. yallundae, given that effective control of only one species will probably select for the other, resulting in continued host infection (Bateman and Jenkyn 2001). However, eyespot (whether caused by $O$. acuformis or $O$. yallundae) is challenging to diagnose accurately in the field because it is only part of the stem-base disease complex of cereals, with other pathogens causing similar disease symptoms including Rhizoctonia cerealis, Fusarium spp., and Microdochium spp. (Nicholson et al. 1997). Moreover, determining whether eyespot is caused by $O$. acuformis, $O$. yallundae, or both is not possible based on visible symptoms alone. Although time consuming and laborious, the species can be discriminated morphologically on potato dextrose agar, with $O$. acuformis colonies typically slower growing and feathery-edged, whereas those of O. yallundae are faster growing and even-edged (Hollins et al. 1985). Molecular PCR-based diagnostics have previously been described for both discrimination and quantification of $O$. acuformis and O. yallundae (Nicholson et al. 1997; Walsh et al. 2005).

Another factor important to consider for eyespot disease is spore production and dispersal. In wet weather, large numbers of conidia are asexually produced by both $O$. acuformis and $O$. yallundae on leftover crop and wild grass debris, and these spores are most often dispersed in the field over short distances by rain splash (Fitt and Bainbridge 1983; Lucas et al. 2000). Sexually produced apothecia, formed on crop or grass straw, have also been reported for both species (Dyer et al. 1994a, 2001a; Dyer and Bradshaw 2002), and ascospores have been shown to infect seedlings (Daniels et al. 1995). Both $O$. acuformis and $O$. yallundae are known to be heterothallic ascomycetes, with isolates of complementary mating type (MAT1-1 and MAT1-2) needed for sexual reproduction (Dyer et al. 1993). Isolates of opposite MAT1-1 and MATl-2 types contain highly dissimilar MAT "idiomorphs" (highly dissimilar stretches of DNA), each containing one to three open reading frames flanked by highly similar neighboring sequences in both mating types (Dyer et al. 2016, 2001b). Apothecia of O. acuformis appear to be less common in the field than those of $O$. yallundae (Douhan et al. 2002a; Dyer and Lucas 1995; Dyer et al. 1994b). Intriguingly, genetic analyses of Oculimacula populations have revealed evidence both for and against an important role for the sexual cycle; for example, similar ratios of both mating types were found in Europe and the United States (Douhan et al. 2002a; Dyer et al. 2001b), with a corresponding high genotypic diversity in some populations (Douhan et al. 2002b, 2003). Conversely, skewed ratios of mating types were found in other populations (e.g., New Zealand; Dyer et al. 2001b), and clonal genotypes dominated some subpopulations such as Washington State (USA) (Douhan et al. 2002b, 2003), where populations were largely homogeneous, with both sexual and asexual reproduction contributing to the population structure.

Pathogens with mixed reproductive systems are considered to have high evolutionary potential and to be better able to overcome disease management strategies, including use of resistant cultivars and fungicides (McDonald and Linde 2002). Therefore, it is useful to be able to assess the potential and impact of sexual reproduction.
Indeed, a multiplex PCR-based diagnostic has previously been used to determine the ratio of mating types of $O$. acuformis and $O$. yallundae in certain worldwide populations to indicate the likelihood of sexual reproduction (Dyer et al. 2001b). Given the challenging process of sexual crossing of $O$. yallundae, and especially O. acuformis, in vitro (Dyer et al. 1993, 1996), such molecular tools have greatly facilitated the determination of mating type. However, the MAT diagnostic of Dyer et al. (2001b) failed to discriminate between $O$. acuformis and $O$. yallundae isolates, instead producing identically sized MAT1-1 and MAT1-2 amplicons for both species.

Recently, an alternative molecular approach, loop-mediated isothermal amplification (LAMP), has been applied for detection of various phytopathogenic fungi and for genetic traits such as fungicide resistance (Aggarwal et al. 2017; Duan et al. 2015; Jędryczka et al. 2013; King et al. 2018; Niessen and Vogel 2010; Rong et al. 2018; Yasuhara-Bell et al. 2018). First proposed by Notomi et al. (2000), LAMP differs from classic PCR by using four to six specific primers, a DNA polymerase with strand displacement activity, and takes place at a constant (isothermal) temperature. LAMP offers several advantages over traditional PCR diagnostics, including increased specificity, efficiency, rapidity (typically $<30 \mathrm{~min}$ ), and potential for use in the field (Wong et al. 2018). To date, however, no LAMP diagnostics have been developed for $O$. acuformis and $O$. yallundae despite their potential use in eyespot disease management.

Given the economic importance of cereal eyespot, the need to diagnose the causative species, and the need to determine the occurrence of sexual reproduction, the described research aimed first to develop a classic PCR-based multiplex test for the simultaneous detection of both species (O. acuformis or O. yallundae) and mating type (MAT1-1 or MAT1-2) in DNA samples and second, to develop complementary LAMP assays for both species and mating-type detection, aimed primarily for use on stem samples. Third, the PCR-based multiplex test was used to examine the dispersal of ascospores of $O$. acuformis and O. yallundae in the field to assess the role of the sexual stage in outbreaks of eyespot disease.

\section{MATERIALS AND METHODS}

Fungal isolates and genomic DNA preparation. Details of the fungal isolates used in this study are provided in Tables 1 and 2 . These included $O$. acuformis and $O$. yallundae cultures studied previously by Dyer et al. (2001b), who used a non-species-specific mating-type multiplex PCR assay to determine isolate MAT1-1 or MAT1-2 identity. Isolates have since been maintained under liquid nitrogen in the BDUN collection at the University of Nottingham (Nottingham, UK). Additional isolates of the closely related species Pyrenopeziza brassicae and Rhynchosporium spp. were obtained from $-80^{\circ} \mathrm{C}$ glycerol stocks at Rothamsted Research (RRes) (Harpenden, UK); the mating types of these isolates were determined from published MAT-specific PCR diagnostics (Foster et al. 2002; King et al. 2015). Other fungal isolates were derived from the University of Nottingham or RRes culture collections and included additional species associated with cereal stem-base diseases of wheat including Fusarium and Microdochium spp. Cultures were incubated at $19^{\circ} \mathrm{C}$ in yeast extract glucose liquid culture to produce mycelium. Genomic DNA was extracted from lyophilized fungal mycelium as described by Dyer et al. (2001b) or a MasterPure Yeast DNA kit (Epicentre, Middleton, WI) according to the manufacturer's protocol. Samples were quantified with a NanoDrop spectrophotometer (Thermo Fisher Scientific, Inc., Waltham, MA), and diluted to $10 \mathrm{ng} / \mu \mathrm{l}$ with PCR-grade water.

Multiplex PCR-based species and mating type detection. Previous work (Dyer et al. 2001b) demonstrated that primer MT5315 annealed to DNA in the idiomorph flanking region common to both $O$. acuformis and O. yallundae MAT1-1 and 
MAT1-2 isolates. The entire mating-type idiomorphs and flanking regions $\leq 12 \mathrm{~kb}$ in size have subsequently been cloned and sequenced from both $O$. acuformis and O. yallundae (Eyres and Dyer, unpublished data, available on request). A species-specific multiplex matingtype PCR diagnostic was therefore designed, using the common primer MT5315 to anneal to the flanking region of both mating types of both species, together with four additional primers (two species-specific and two mating-type-specific primers; Fig. 1). The set of primers YM1, YM2, AcuM1, and AcuM2 (Table 3) was designed based on multiple alignments of the sequence data from
MAT1-1 and MAT1-2 regions of two representative isolates from each of $O$. acuformis and $O$. yallundae, with the criterion that the primer combinations would amplify products of different sizes dependent on the template DNA.

The multiplex primer set was used in 25- $\mu$ l amplification reactions consisting of $25 \mathrm{pmol}$ of each primer, $2.5 \mu \mathrm{l}$ of $10 \times$ reaction buffer, one unit of Red Hot DNA polymerase (Abgene, Thermo Fisher Scientific, Inc.), $200 \mu \mathrm{mol}$ dNTPs and approximately $10 \mathrm{ng}$ of genomic DNA. PCR used a touchdown approach and was run on a thermocycler with cycling parameters of 8 cycles

TABLE 1. Isolates used for validation of Oculimacula acuformis or $O$. yallundae and mating-type (MAT1-1 or MAT1-2) specific multiplex PCR assay ${ }^{\text {a }}$

\begin{tabular}{|c|c|c|c|c|}
\hline Isolate code & Species & Geographic origin or source & Mating type ${ }^{\mathrm{b}}$ & Multiplex PCR diagnostic result \\
\hline $22-418$ & O. acuformis & Gloucestershire, U.K. & MAT1-1 & O. acuformis MAT1-1 \\
\hline $22-419$ & O. acuformis & Wiltshire, U.K. & MAT1-1 & O. acuformis MAT1-1 \\
\hline $22-420$ & O. acuformis & Norfolk, U.K. & MAT1-1 & O. acuformis MAT1-1 \\
\hline $22-427$ & O. acuformis & Norfolk, U.K. & MAT1-2 & O. acuformis MAT1-2 \\
\hline $22-476$ & O. acuformis & Belgium & $M A T 1-1$ & O. acuformis MAT1-1 \\
\hline $22-486$ & O. acuformis & Thorembais, Belgium & MAT1-1 & O. acuformis MAT1-1 \\
\hline $22-488$ & O. acuformis & France & MAT1-2 & O. acuformis MAT1-2 \\
\hline $22-496$ & O. acuformis & Germany & MAT1-1 & O. acuformis MAT1-1 \\
\hline $22-498$ & O. acuformis & Germany & $M A T 1-2$ & O. acuformis MAT1-2 \\
\hline $38-30-1$ & O. acuformis & Lincolnshire, U.K. & MAT1-1 & O. acuformis MAT1-1 \\
\hline $38-30-2$ & O. acuformis & Lincolnshire, U.K. & MAT1-2 & O. acuformis MAT1-2 \\
\hline $38-30-9$ & O. acuformis & Lincolnshire, U.K. & MAT1-2 & O. acuformis MAT1-2 \\
\hline $38-30-20$ & O. acuformis & Lincolnshire, U.K. & MAT1-1 & O. acuformis MAT1-1 \\
\hline $99-3-1$ & O. acuformis & Washington State, U.S.A. & MAT1-2 & O. acuformis MAT1-2 \\
\hline $99-4-3$ & O. acuformis & Washington State, U.S.A. & MAT1-1 & O. acuformis MAT1-1 \\
\hline $99-5-1$ & O. acuformis & Washington State, U.S.A. & MAT1-2 & O. acuformis MAT1-2 \\
\hline $99-6-1$ & O. acuformis & Washington State, U.S.A. & MAT1-1 & O. acuformis MAT1-1 \\
\hline $99-9-7$ & O. acuformis & Washington State, U.S.A. & $M A T 1-2$ & O. acuformis MAT1-2 \\
\hline $99-10-1$ & O. acuformis & Washington State, U.S.A. & MAT1-1 & O. acuformis MAT1-1 \\
\hline $99-26-10$ & O. acuformis & Oregon, U.S.A. & MAT1-1 & O. acuformis MAT1-1 \\
\hline $99-29-2$ & O. acuformis & Washington State, U.S.A. & MAT1-1 & O. acuformis MAT1-1 \\
\hline $99-32-5$ & O. acuformis & Oregon, U.S.A. & MAT1-2 & O. acuformis MAT1-2 \\
\hline $99-34-3$ & O. acuformis & Oregon, U.S.A. & MAT1-2 & O. acuformis MAT1-2 \\
\hline $1-2-7$ & O. yallundae & Wairarapa, New Zealand & MAT1-2 & O. yallundae MAT1-2 \\
\hline $11-2-12$ & O. yallundae & Southland, New Zealand & MAT1-2 & O. yallundae MAT1-2 \\
\hline $11-3-18$ & O. yallundae & Southland, New Zealand & MAT1-1 & O. yallundae MAT1-1 \\
\hline $11-4-5$ & O. yallundae & Southland, New Zealand & MAT1-1 & O. yallundae MAT1-1 \\
\hline $22-380$ & O. yallundae & Nottinghamshire, U.K. & MAT1-1 & O. yallundae MAT1-1 \\
\hline $22-416$ & O. yallundae & Suffolk, U.K. & MAT1-1 & O. yallundae MAT1-1 \\
\hline $22-417$ & O. yallundae & Hertfordshire, U.K. & MAT1-1 & O. yallundae MAT1-1 \\
\hline $22-432$ & O. yallundae & Cambridgeshire, U.K. & MAT1-2 & O. yallundae MAT1-2 \\
\hline $22-433$ & O. yallundae & Bedfordshire, U.K. & MAT1-1 & O. yallundae MAT1-1 \\
\hline $22-434$ & O. yallundae & Cambridgeshire, U.K. & MAT1-2 & O. yallundae MAT1-2 \\
\hline $22-435$ & O. yallundae & Cambridgeshire, U.K. & MAT1-1 & O. yallundae MAT1-1 \\
\hline $22-439$ & O. yallundae & Hertfordshire, U.K. & MAT1-2 & O. yallundae MAT1-2 \\
\hline $22-445$ & O. yallundae & Pouilly-le-Fort, France & MAT1-1 & O. yallundae MAT1-1 \\
\hline $22-481$ & O. yallundae & Thorembais, Belgium & MAT1-2 & O. yallundae MAT1-2 \\
\hline $22-482$ & O. yallundae & Thorembais, Belgium & MAT1-1 & O. yallundae MAT1-1 \\
\hline $22-483$ & O. yallundae & Belgium & MAT1-2 & O. yallundae MAT1-2 \\
\hline $22-494$ & O. yallundae & France & MAT1-2 & O. yallundae MAT1-2 \\
\hline $22-495$ & O. yallundae & Germany & MAT1-2 & O. yallundae MAT1-2 \\
\hline $22-500$ & O. yallundae & Germany & MAT1-1 & O. yallundae MAT1-1 \\
\hline $37-18-6$ & O. yallundae & Laboratory cross $22-432 \times 22-433$ & MAT1-2 & O. yallundae MAT1-2 \\
\hline $37-39-3$ & O. yallundae & Essex, U.K. & MAT1-1 & O. yallundae MAT1-1 \\
\hline F616 & Fusarium avenaceum & Not available & No data & No product \\
\hline F95 & F. sambucinum & Not available & No data & No product \\
\hline $239^{c}$ & F. avenaceum & Not available & No data & No product \\
\hline $\mathrm{F} 500^{\mathrm{c}}$ & F. graminearum & Not available & No data & No product \\
\hline IL5 $^{\mathrm{c}}$ & F. graminearum & Not available & No data & No product \\
\hline $\mathrm{CSL8}^{\mathrm{c}}$ & F. poae & Not available & No data & No product \\
\hline $1160^{\mathrm{c}}$ & F. crookwellense & Not available & No data & No product \\
\hline $116^{\mathrm{c}}$ & F. crookwellense & Not available & No data & No product \\
\hline 97FT18c & F. tricinctum & Not available & No data & No product \\
\hline $\mathrm{Mn} 1^{\mathrm{c}}$ & Microdochium nivale var. nivale & Not available & No data & No product \\
\hline $153 / 8^{\mathrm{c}}$ & M. nivale var. nivale & Not available & No data & No product \\
\hline $161 / 14^{c}$ & M. nivale var. majus & Not available & No data & No product \\
\hline $161 / 23^{c}$ & M. nivale var. majus & Not available & No data & No product \\
\hline
\end{tabular}

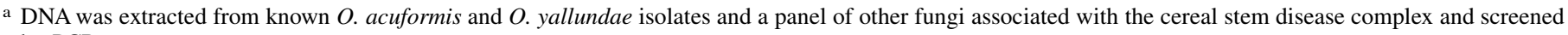
by PCR.

b As determined by the multiplex PCR diagnostic of Dyer et al. (2001b).

c Cultures obtained from P. Nicholson (John Innes Centre, Norwich, UK). 
of $94^{\circ} \mathrm{C}$ for $1 \mathrm{~min}, 59.9^{\circ} \mathrm{C}$ for $1 \mathrm{~min}$ (first cycle, reducing by $0.2^{\circ} \mathrm{C}$ each subsequent cycle), and $72^{\circ} \mathrm{C}$ for $1 \mathrm{~min} ; 35$ cycles of $94^{\circ} \mathrm{C}$ for $1 \mathrm{~min}, 58.5^{\circ} \mathrm{C}$ for $1 \mathrm{~min}$, and $72^{\circ} \mathrm{C}$ for $1 \mathrm{~min} ; 72^{\circ} \mathrm{C}$ for $10 \mathrm{~min}$; and $4^{\circ} \mathrm{C}$ for $30 \mathrm{~min}$ (all at maximum ramp rate). The species- and mating-type-specific primers were also tested individually with primer MT5315 to ensure that they amplified the correct product from given DNA templates. Subsequently, gels were stained with an ethidium bromide solution $(0.2 \mathrm{mg}$ of ethidium bromide per $100 \mathrm{ml}$ $1 \times$ Tris-Borate-EDTA [TBE buffer; National Diagnostics, Nottingham, UK]), visualized under ultraviolet light, and scored for the presence of the correct-sized predicted product. The multiplex PCR was tested against a range of isolates of $O$. acuformis and $O$. yallundae from diverse geographic origins, as well as Fusarium and Microdochium spp. associated with the cereal stem-base disease complex, as previously used as negative controls by Nicholson et al. (1997) (Table 1).

LAMP assay primer design, specificity, and sensitivity testing. To design the LAMP assays, Oculimacula spp. and related pathogen target sequences were obtained from GenBank and aligned via Clustal W in Geneious (version 8.1.3; Biomatters Ltd,
Auckland, New Zealand). Primer sets were designed with the free online software package PrimerExplorer version 5 (Eiken Chemical Co. Ltd., Tokyo, Japan; http://primerexplorer.jp/e) using default settings. For two new $O$. acuformis and $O$. yallundae speciesspecific LAMP assays, primers were designed with $\beta$-tubulin gene sequences from $O$. acuformis (GenBank accession numbers MT253741 and MT253742) and O. yallundae (MT253743); the closely related Rhynchosporium (X81046) and P. brassicae (KC342227) (Goodwin 2002); and the more distantly related Aspergillus flavus (M38265), Botrytis cinerea (MG949125), Clarireedia homoeocarpa (MF969129), Monilinia fructicola (AY283678), and Sclerotinia sclerotiorum (MH796665). Four of the "common" primers (F3, B3, LF, and LB) were designed for use with both Oculimacula species-specific LAMP assays and targeted sequences common to both species; two different "specific" FIP/ BIP primer pairs were designed for use with either the O. acuformisor $O$. yallundae-specific assay and targeted sequence variation between the species. For new mating-type-specific LAMP assays, primers were targeted to either the MAT1-1 or MAT1-2 genes of the Oculimacula species (but not to those same genes present in

TABLE 2. Isolates used for validation of new Oculimacula acuformis or $O$. yallundae and mating-type (MAT1-1 or MAT1-2) specific loop-mediated isothermal amplification (LAMP) assays ${ }^{\mathrm{a}}$

\begin{tabular}{|c|c|c|c|c|c|c|c|}
\hline \multirow[b]{3}{*}{ Isolate code } & \multirow[b]{3}{*}{ Species } & \multirow[b]{3}{*}{ Geographic origin } & \multirow[b]{3}{*}{$\begin{array}{l}\text { Mating } \\
\text { type }^{\mathrm{b}}\end{array}$} & \multicolumn{4}{|c|}{ LAMP assay results $^{\mathrm{c}}$} \\
\hline & & & & \multicolumn{2}{|c|}{$\begin{array}{c}\text { Oculimacula species-specific } \\
\text { LAMP assays }\end{array}$} & \multicolumn{2}{|c|}{$\begin{array}{l}\text { Mating-type specific LAMP } \\
\text { assay (for } O \text {. acuformis and } \\
\text { O. yallundae) }\end{array}$} \\
\hline & & & & $\begin{array}{l}\text { O. acuformis- } \\
\text { specific assay }\end{array}$ & $\begin{array}{l}\text { O. yallundae- } \\
\text { specific assay }\end{array}$ & $\begin{array}{c}\text { MATl-1 } \\
\text { specific assay }\end{array}$ & $\begin{array}{c}\text { MAT1-2 } \\
\text { specific assay }\end{array}$ \\
\hline $22-418$ & O. acuformis & Gloucestershire, U.K. & MAT1-1 & $+(7.52 \mathrm{~min})$ & - & $+(9.17 \mathrm{~min})$ & - \\
\hline $22-422$ & O. acuformis & Leicestershire, U.K. & MAT1-1 & $+(7.59 \mathrm{~min})$ & - & $+(9.61 \mathrm{~min})$ & - \\
\hline $22-424$ & O. acuformis & Cambridgeshire, U.K. & MAT1-1 & $+(7.01 \mathrm{~min})$ & - & $+(9.4 \mathrm{~min})$ & - \\
\hline $22-426$ & O. acuformis & Norfolk, U.K. & MAT1-1 & $+(8.14 \mathrm{~min})$ & - & $+(10.78 \mathrm{~min})$ & - \\
\hline $22-476$ & O. acuformis & Belgium & MAT1-1 & $+(7.31 \mathrm{~min})$ & - & $+(8.43 \mathrm{~min})$ & - \\
\hline $22-489$ & O. acuformis & France & MAT1-1 & $+(7.28 \mathrm{~min})$ & - & $+(9.65 \mathrm{~min})$ & - \\
\hline $22-490$ & O. acuformis & France & MAT1-1 & $+(7.72 \mathrm{~min})$ & - & $+(10.66 \mathrm{~min})$ & - \\
\hline $22-493$ & O. acuformis & France & MAT1-2 & $+(7.30 \mathrm{~min})$ & - & - & $+(6.72 \mathrm{~min})$ \\
\hline $22-496$ & O. acuformis & Germany & MAT1-1 & $+(7.25 \mathrm{~min})$ & - & $+(9.36 \mathrm{~min})^{\mathrm{d}}$ & $+(16.3 \mathrm{~min})^{\mathrm{d}}$ \\
\hline $22-498$ & O. acuformis & Germany & MAT1-2 & $+(7.13 \mathrm{~min})$ & - & - & $+(6.56 \mathrm{~min})$ \\
\hline $22-499$ & O. acuformis & Germany & MAT1-1 & $+(7.32 \mathrm{~min})$ & - & $+(9.98 \mathrm{~min})$ & - \\
\hline $11-4-5$ & O. yallundae & Southland, New Zealand & MAT1-1 & - & $+(6.85 \mathrm{~min})$ & $+(7 \mathrm{~min})$ & - \\
\hline $22-417$ & O. yallundae & Hertfordshire, U.K. & MAT1-1 & - & $+(6.52 \mathrm{~min})$ & $+(6.5 \mathrm{~min})$ & - \\
\hline $22-433$ & O. yallundae & Bedfordshire, U.K. & MAT1-1 & - & $+(7.34 \mathrm{~min})$ & $+(7.60 \mathrm{~min})$ & - \\
\hline $22-434$ & O. yallundae & Cambridgeshire, U.K. & MAT1-2 & - & $+(6.77 \mathrm{~min})$ & - & $+(5.68 \mathrm{~min})$ \\
\hline $22-445$ & O. yallundae & Pouilly-le-Fort, France & MAT1-1 & - & $+(6.35 \mathrm{~min})$ & $+(8 \min )$ & - \\
\hline $22-480$ & O. yallundae & Belgium & MAT1-1 & - & $+(7.23 \mathrm{~min})$ & $+(7.51 \mathrm{~min})$ & - \\
\hline $22-482$ & O. yallundae & Thorembais, Belgium & MAT1-1 & - & $+(6.62 \mathrm{~min})$ & $+(7.06 \mathrm{~min})$ & - \\
\hline $22-491$ & O. yallundae & France & MAT1-1 & - & $+(6.15 \mathrm{~min})$ & $+(6.07 \mathrm{~min})^{\mathrm{d}}$ & $+(10.32 \mathrm{~min})^{\mathrm{d}}$ \\
\hline $22-495$ & O. yallundae & Germany & MAT1-2 & - & $+(6.10 \mathrm{~min})$ & - & $+(5.13 \mathrm{~min})$ \\
\hline \multicolumn{8}{|l|}{$\begin{array}{l}\text { RS04CG- } \\
\text { RAC- }\end{array}$} \\
\hline A.6. $1^{\mathrm{e}}$ & Rhynchosporium agropyri & Switzerland & MAT1-2 & - & - & - & - \\
\hline $27 \mathrm{dg} 09^{\mathrm{e}}$ & Rhynchosporium orthosporum & Aberystwyth, U.K. & MAT1-1 & - & - & - & - \\
\hline 17KALE02 & Pyrenopeziza brassicae & Lincolnshire, U.K. & MAT1-1 & - & - & - & - \\
\hline $\mathrm{E} 3 \mathrm{a}^{\mathrm{e}}$ & P. brassicae & Hertfordshire & MAT1-2 & nt & nt & - & - \\
\hline $\mathrm{Ab}$ A54 & Alternaria brassicae & U.K. & No data & - & - & nt & nt \\
\hline Fo F9 & Fusarium oxysporum & No data & No data & - & - & $\mathrm{nt}$ & nt \\
\hline Lm A3 & Leptosphaeria maculans & Hertfordshire, U.K. & No data & - & - & nt & nt \\
\hline Lm A4 & L. maculans & Hertfordshire, U.K. & No data & - & - & nt & nt \\
\hline \multicolumn{8}{|l|}{ Vd NR-2 } \\
\hline FITO & Verticillium dahliae & Poland & No data & - & - & $\mathrm{nt}$ & nt \\
\hline \multicolumn{8}{|l|}{ Vd RES/ } \\
\hline SU/9 & V. dahliae & U.K. & No data & - & - & $\mathrm{nt}$ & nt \\
\hline Ss M3O & Sclerotinia sclerotiorum & Hertfordshire, U.K. & No data & - & - & nt & nt \\
\hline Ss PY2 & S. sclerotiorum & Hertfordshire, U.K. & No data & - & - & nt & nt \\
\hline
\end{tabular}

${ }^{a}$ DNA was extracted from known $O$. acuformis and $O$. yallundae isolates and a panel of other ascomycete fungi and screened by LAMP.

b As determined by the multiplex PCR diagnostic of Dyer et al. (2001b).

c + , positive followed by time to positive result in parentheses; -, negative (i.e., no product); and nt, not tested.

d Note that for these two isolates, identified as MAT1-1 by Dyer et al. (2001b), the time to positive result was fastest with the new MAT1-1-specific LAMP assay. The additional MAT1-2 LAMP amplicon was produced at a slower rate and is considered an artifact of the extended incubation.

e The applicability of these DNA extracts to LAMP had been confirmed previously when screened against either Rhynchosporium-specific (K. King, unpublished data) or P. brassicae-specific (King et al. 2018) LAMP assays as appropriate. 
Pyrenopeziza or Rhynchosporium spp.). For design of the MAT1-1 assay primers, the sequences from O. acuformis (MT274722), O. yallundae (AF342951), Rhynchosporium (AJ549759), and P. brassicae (AJ006073) were used. For design of the MAT1-2 assay primers, the sequences from $O$. acuformis (MT253744), O. yallundae (MT253745), Rhynchosporium (AJ537511), and $P$. brassicae (AJ006072) were used.

The four newly designed LAMP assays were tested for their specificity to their respective targets by screening against DNA from a range of isolates of $O$. acuformis and $O$. yallundae from diverse geographic origins, together with a panel of various related ascomycete fungal species (Table 2). LAMP reactions were performed in $15-\mu 1$ volumes containing $0.3 \mu \mathrm{l}$ of FIP (100 $\mu$ m primer stock), $0.3 \mu \mathrm{l}$ of BIP $(100 \mu \mathrm{m}), 0.15 \mu \mathrm{l}$ of LoopF $(100 \mu \mathrm{m}), 0.15 \mu \mathrm{l}$ of LoopB $(100 \mu \mathrm{m})$, $0.3 \mu \mathrm{l}$ of $\mathrm{F} 3(10 \mu \mathrm{m}), 0.3 \mu \mathrm{l}$ of B3 $(10 \mu \mathrm{m}), 7.5 \mu \mathrm{l}$ of isothermal master mix (Optigene Ltd., Horsham, West Sussex, U.K.; ISO001, $2 \times$ concentrate), $5 \mu \mathrm{l}$ of PCR-grade water, and $1 \mu \mathrm{l}$ of template genomic DNA (10 ng total). All testing was done in an MX3000p quantitative PCR system (Agilent Technologies Inc., Santa Clara, CA), with each run including no-template water controls. Reaction conditions were 60 cycles of either $63^{\circ} \mathrm{C}$ (for both of the $O$. acuformis and $O$. yallundae species-specific LAMP assays) or $65^{\circ} \mathrm{C}$ (for both of the MAT1-1 and MAT1-2 LAMP assays) for $30 \mathrm{~s}$ (during which accumulation of fluorescent double-stranded DNA intercalating dye from the master mix was measured via the Mx3000P FAM channel), with a final dissociation step at $95^{\circ} \mathrm{C}$ for $1 \mathrm{~min}, 55^{\circ} \mathrm{C}$ for $30 \mathrm{~s}$, and $95^{\circ} \mathrm{C}$ for $30 \mathrm{~s}$. Data were processed in 7500 SDS software version 1.4 (Applied Biosystems, Waltham, MA) and analyzed on a log scale with the cycle threshold $(\mathrm{Ct})$ manually adjusted to the exponential phase of amplification curves. Samples that produced a clear amplification curve ( $\mathrm{Ct}$ values $<60$, i.e., within $30 \mathrm{~min}$ ) and a single clear dissociation peak at the expected temperature were considered positive. All individual samples were tested with LAMP with two technical replicates, from which mean values were determined.

For sensitivity testing of the new LAMP assays, DNA extracts from three Oculimacula isolates were quantified with a Qubit dsDNA HS Assay Kit (Thermo Fisher Scientific, Inc.) and a Qubit Fluorometer 2.0. Each of the four new LAMP assays was screened against different amounts of target genomic DNA from a single isolate of each species ( $O$. acuformis assay, isolate 22-493; O. yallundae assay, 22-491; MAT1-1 assay, 22-491; MAT1-2 assay, 22-495). Total amounts of target DNA per reaction tested in duplicate were 500, 100, 20, $10 \mathrm{pg}, 4,2$, and $1 \mathrm{pg}$.

Application of LAMP assays in planta. Fifteen wheat stem samples with visible external eyespot symptoms were collected in the Czech Republic between 2014 and 2016 at two different geographic sites: Kroměříž and Prague (Table 4). To act as negative control samples, two wheat stem segments (samples 24 and 25) were collected from Prague that had no external eyespot symptoms; that is, they appeared visually healthy (although it was recognized that the possible cryptic, symptomless infections of these samples might also give positive results). Thus, two additional samples of crushed stem and leaf tissue of oilseed rape (Brassica napus), a nonhost species with no visible disease (samples 38 and 39), were also included as controls. Genomic DNA was extracted from about 50 to $100 \mathrm{mg}$ of powdered plant tissue sample with a MasterPure Yeast DNA kit, quantified via NanoDrop, and diluted to $10 \mathrm{ng} / \mu \mathrm{l}$. DNA extracts from these plant samples were tested via both conventional endpoint PCR (Walsh et al. 2005) and the new $O$. acuformis and $O$. yallundae species-specific LAMP assays. For each of these assays, $O$. acuformis and $O$. yallundae fungal DNA from reference strains were included as positive controls, and PCRgrade water acted as a negative control.

Endpoint PCR was performed with previously published $O$. acuformis and $O$. yallundae species-specific primers; one "common" primer targeted both $O$. acuformis and $O$. yallundae (OccR, 5'-ATTCAAGGGTGGAGGTCTGRA-3'), and specific primers were targeted to either $O$. yallundae (Yall $\mathrm{FH}, 5^{\prime}$ GGGGGCTACCCTACTTGGCAG-3') or $O$. acuformis (Acu FD, 5'-GCCACCCTACTTCGGTAA-3') (Walsh et al. 2005). Each endpoint PCR was performed in 20 - $\mu$ l volumes and contained $0.5 \mu \mathrm{l}$ of primer OccR $(0.5 \mu \mathrm{m}$ final concentration $), 0.5 \mu \mathrm{l}$ of either primer Yall FH or Acu FD $(0.5 \mu$ m final concentration $), 10 \mu$ l of RedTaq $(2 \times$ concentrate, Sigma Aldrich, UK), $6.5 \mu \mathrm{l}$ of PCR-grade water, and $2.5 \mu \mathrm{l}$ of DNA ( $25 \mathrm{ng}$ total). Reaction conditions were 30 cycles of $94^{\circ} \mathrm{C}$ for $30 \mathrm{~s}, 60^{\circ} \mathrm{C}$ for $30 \mathrm{~s}$, and $72^{\circ} \mathrm{C}$ for $30 \mathrm{~s}$, with an additional final extension of $72^{\circ} \mathrm{C}$ for $5 \mathrm{~min}$. Alongside an EasyLadder 1

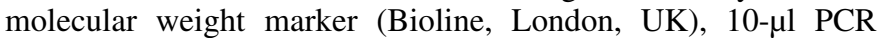
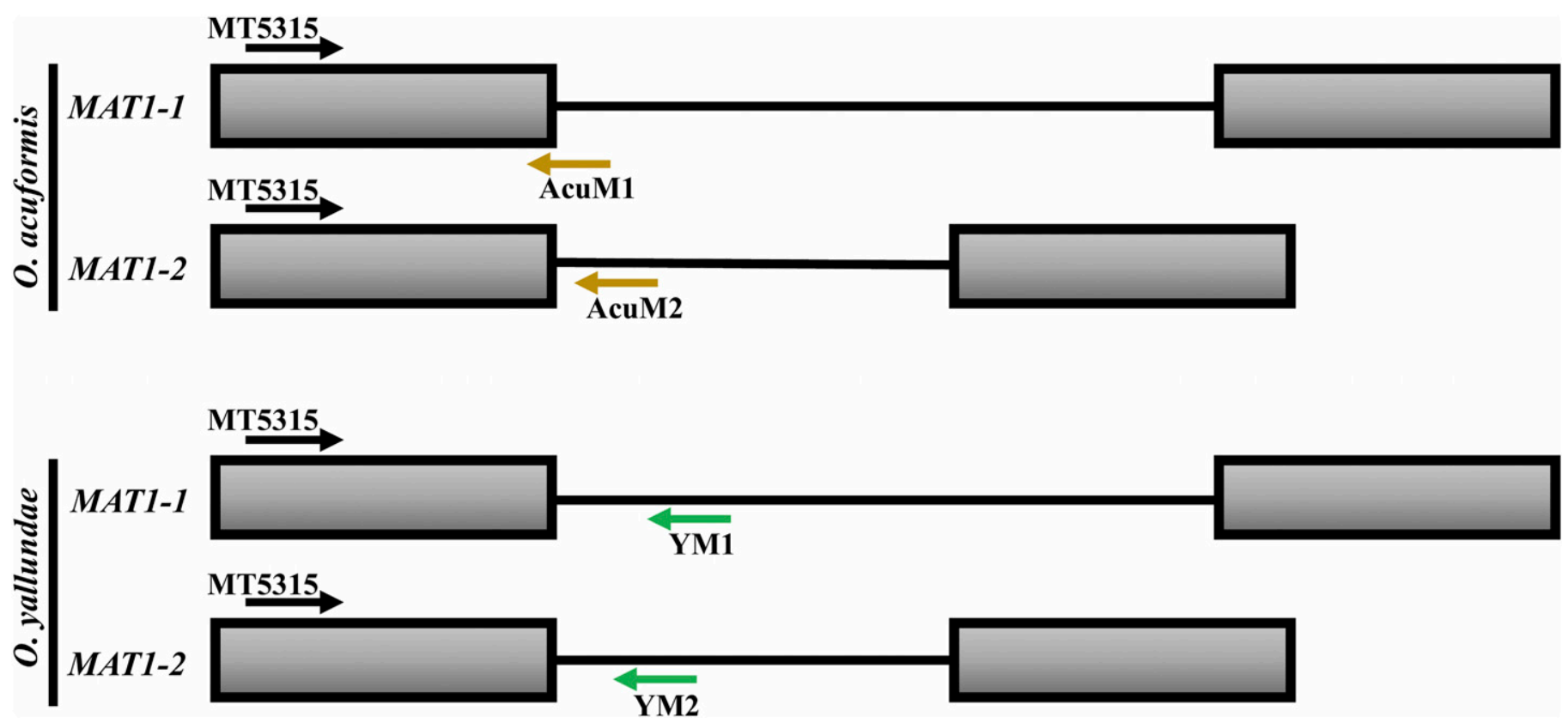

Fig. 1. Schematic of the multiplex PCR diagnostic for simultaneous determination of species and mating-type identity in Oculimacula acuformis and $O$. yallundae. Drawn to approximate scale to show the locations of primers (MT5315, AcuM1, AcuM2, YM1, and YM2), idiomorph regions (bold lines), and the conserved flanking regions (gray boxes). The primer pairs are designed to produce different (diagnostic) sized amplicons between 250 and 900 bp in size. 
amplicons were resolved on a $2 \%$ agarose gel incorporated with $5 \mu \mathrm{l}$ GelRed (10,000× concentrate; Biotium Inc., Hayward, CA). Amplicons were viewed under a high-performance ultraviolet transilluminator and photographed.

LAMP was carried out as previously described for the new $O$. acuformis- and O. yallundae-specific assays. However, the amount of DNA added was increased to $25 \mathrm{ng}$ total per reaction, and reactions were run for 40 cycles (i.e., $20 \mathrm{~min}$ total).

Ascospore discharge and dispersal in the field. To seek evidence of ascospore discharge and dispersal under field conditions, two 6-m² field plot trials were run from 2003 to 2004 at Little Knott Field, RRes, United Kingdom (latitude 51.809569, longitude -0.375862) and Mill Dam III Field, Woburn Farm, United Kingdom (latitude 52.014372, longitude -0.597674). The plots were drilled in October 2003 with winter wheat cultivar 'Hereward' at $350 \mathrm{seeds} / \mathrm{m}^{2}$ and inoculated in December 2003 with inoculum of sexually compatible MAT1-1 and MAT1-2 isolates of $O$. yallundae (22-432 and 22-433, respectively; Dyer et al. 1993) prepared on autoclaved oats according to Dyer et al. (2001a), adding approximately $28 \mathrm{~g} / \mathrm{m}^{2}$ of the dried, mixed oat inoculum. Eyespot within the plots was monitored by collection of 60 to 72 wheat stems from six sampling points from sites in either late June or early July 2004, with stems being scored according to the disease prevalence method of Scott and Hollins (1974). Subsequently, a disease index score was calculated in accordance with Turner et al. (2001). Standing straw stubble left after harvest was checked for the formation of apothecia, as described by Dyer et al. (2001a). It is noted that ascospore dispersal of only $O$. yallundae was studied because of the known difficulties of inducing the sexual cycle of O. acuformis under field conditions (Dyer et al. 2001a).

Spore trapping experiments were conducted to assess possible ascospore production and dispersal. A Burkard 7-day spore trap was initially placed at the center of the inoculated plot in March 2005 (when ascospore dispersal was expected; Dyer et al. 1994a, 2001a), before being moved $2 \mathrm{~m}$ downwind of the plot in April 2005.
Potential spore discharge was collected on petroleum jelly-coated sampling tape with a 2-mm air inlet orifice located at a height of approximately $50 \mathrm{~cm}$, with a motor providing a constant air flow through the inlet of 10 liters/min (Lacey and West 2006). Spore trap tape samples were divided into 24 -h sample sections corresponding to $48 \mathrm{~mm}$ in length $\times 20 \mathrm{~mm}$ width. They were subsequently subdivided longitudinally along the center of the 14-mm width of deposited air particulates to form two subsamples of deposited spores $48 \mathrm{~mm} \times 7 \mathrm{~mm}$ on tape. One of the tape pieces was examined via microscopy by mounting the tape on slides with Euperal (Sigma Aldrich) and stained with lactophenol cotton blue to make spore visualization easier (Lacey and West 2006). The second piece of tape was placed into a 2-ml screw-top tube and disrupted by agitation in the presence of $200 \mu \mathrm{l}$ of $0.1 \%$ Nonidet P40 detergent (Sigma Aldrich) and $0.2 \mathrm{~g}$ of acid-washed Ballotini glass beads ( 400 to $600 \mu \mathrm{m}$ diameter) with a Mikro-Dismembrator (Sartorius AG, Göttingen, Germany) (Calderon et al. 2002). After agitation, $100 \mu \mathrm{l}$ of the spore disruption solution was mixed with $200 \mu \mathrm{l}$ of a DNA extraction buffer and DNA extracted according to Dyer et al. (2001b). Finally, $2 \mu \mathrm{l}$ of the putative DNA extracts were used in PCR assays with the newly developed species and mating-type-specific multiplex DNA diagnostic as described previously, with primers MT5315, YM1, YM2, AcuM1, and AcuM2. In addition, control experiments were run with known numbers of ascospores of O. yallundae $(1,10,100,1,000)$ added as droplets of spore suspension to sections of Melinex tape and dried in a sterile flow cabinet, and the same DNA extraction process was repeated to ensure reliability of the process.

\section{RESULTS}

Multiplex PCR-based species and MAT identity diagnostic. When tested by PCR with the common forward primer MT5315, the four reverse primers (YM1, YM2, AcuM1, and AcuM2) were individually found to amplify products of the expected sizes when

TABLE 3. Primer sequences for Oculimacula acuformis and $O$. yallundae species-specific and mating-type-specific classic PCR or loop-mediated isothermal amplification (LAMP) diagnostic assays

\begin{tabular}{|c|c|}
\hline Primer use and code & Oligonucleotide sequence $\left(5^{\prime}-3^{\prime}\right)$ \\
\hline \multicolumn{2}{|c|}{ Oculimacula species-specific and mating-type-specific classic PCR multiplex } \\
\hline MT5315 & AGGAGGGCTACTGGAGGTG \\
\hline YM1 & CGAATCTCCTCTTCATCAG \\
\hline AcuM1 & CCACATCTCCCGATCTCCAT \\
\hline AcuM2 & TCCCGTCGGATGCATACTTT \\
\hline \multicolumn{2}{|c|}{ Oculimacula species-specific LAMP assays (“common” primers) } \\
\hline OA/OY_F3 & TTCCCTCGTCTCCATTTCT \\
\hline OA/OY_LB & TCTGCCATCTTGTAAGTCATCC \\
\hline \multicolumn{2}{|c|}{ Primers for use only with $O$. acuformis species-specific LAMP assay } \\
\hline OA_FIP & AATCGGAAGCAGCCATCATGTCGTCACCGTCCCAGAGT \\
\hline \multirow{2}{*}{\multicolumn{2}{|c|}{ Primers for use only with $O$. yallundae species-specific LAMP assay }} \\
\hline & \\
\hline OY_FIP & AATCGGAAGCAGCCATCATGTCGTTACCGTCCCAGAGT \\
\hline OY_BIP & ACGGTCGCTACTTGACTTGCGAAGTCAGTGTTAAGTAACGGT \\
\hline OC_MAT1_LF & CCCCTTCAAGGCAAAGTGG \\
\hline OC_MAT1_LB & AGGCTACTTAAGAGTTAACACAG \\
\hline \multicolumn{2}{|c|}{ O. acuformis $+O$. yallundae MAT1-2 specific LAMP assay } \\
\hline OC_MAT2_F3 & TCATTGCGCAATACCAGGAG \\
\hline OC_MAT2_B3 & CTGCCAGCTGCAAAGGTA \\
\hline OC_MAT2_FIP & GCGGGGTTGGTACTGGTAGTTGCTTGCTAAGCAGGCTAAGGC \\
\hline OC_MAT2_BIP & TCGAGTGAGAAGAAGCGTCGCATATGGGCCAGTCTGAGCG \\
\hline OC_MAT2_LF & GTTGTTCGCCAGATGCTGT \\
\hline OC_MAT2_LB & TGACCAAGAAGAAGGCTGCTA \\
\hline
\end{tabular}


DNA from the appropriate species and of the appropriate mating type was used: a 250-bp product for $O$. acuformis MAT1-1, a 600bp product for $O$. acuformis MAT1-2, a 900-bp product for O. yallundae MAT1-1, and a 700-bp product for O. yallundae MAT1-2 (Fig. 1). When the primers were used in multiplex PCR with template DNA from 23 O. acuformis isolates from various locations in Europe and the United States and $21 O$. yallundae isolates from various locations in Europe and New Zealand, they consistently gave a single amplicon of the correct predicted size according to the species and mating-type identity of the isolate concerned (Fig. 2; Table 1). The use of touchdown PCR overcame an issue of faint secondary bands that were seen very occasionally without the touchdown procedure. To ensure that amplified products were from the Oculimacula MAT region, representative bands were gel purified and sequenced, and the resulting sequences were found to exhibit $100 \%$ homology to the matching $O$. acuformis or $O$. yallundae mating-type region (data not shown). Importantly, no PCR product was produced from DNA templates of other cereal stem-base phytopathogens (Fusarium and Microdochium spp.; Table 1), indicating the specificity of the multiplex PCR for detection of Oculimacula species. Two other sets of multiplex primers were also assayed for species and mating-type identification of $O$. acuformis and $O$. yallundae, but these failed to give the robust and reliable amplification of single amplicons seen with primers MT5315 and YM1, YM2, AcuM1, and AcuM2 (Eyres 2007).

Validation of new $O$. acuformis and $O$. yallundae speciesspecific and mating-type LAMP assays. The specificity of the new LAMP assays was confirmed by screening against template DNA from $11 O$. acuformis and $9 O$. yallundae isolates from various locations in Europe and New Zealand (Table 2). The species-specific LAMP assays, when tested with $10 \mathrm{ng}$ of total fungal isolate DNA in the reaction, gave positive results (i.e., clear amplification curves), all within the first 9 min of the 30-min total reaction time only for their respective target Oculimacula pathogen species; neither assay gave false positive results over 30 min against DNA (also $10 \mathrm{ng}$ total in reaction) of other closely related fungal species (e.g., P. brassicae, Rhynchosporium spp.), or other major wheat pathogens. Both of the assays could detect small amounts $(1 \mathrm{pg})$ of $O$. acuformis or $O$. yallundae template DNA, although detection of such small amounts of template meant that the time taken for a positive result to be obtained was slightly longer (but still within the first 15 min of the 30-min total reaction time) (Fig. 3A); positive results for each of the species-specific assays gave single distinct dissociation melting curve peaks (O. acuformis assay, $88.5^{\circ} \mathrm{C}$; O. yallundae assay, $88^{\circ} \mathrm{C}$; Supplementary Fig. S1A and B), indicating target specificity. Similarly, the specificity of the new mating-type-specific assays was also confirmed by testing, with conclusive results typically obtained in $<12 \mathrm{~min}$; here positive results for each of the mating-type-specific assays also gave single distinct dissociation melting curve peaks (MAT1-1 assay, $87.4^{\circ} \mathrm{C}$; $M A T 1-2$ assay, $90.5^{\circ} \mathrm{C}$; Supplementary Fig. S1C and D), indicating target specificity. The new MATspecific assays were sensitive and could detect even small amounts (1 pg) of target MAT1-1 or MAT1-2 isolate DNA (Fig. 3B). However, it is noted that two anomalous results were obtained via the new MAT-specific LAMP assays: Isolates 22-496 (O. acuformis, Germany) and 22-491 (O. yallundae, France) yielded both MAT1-1 and MAT1-2 positive results. In both cases the MAT1-1 signal was produced more rapidly, indicating larger amounts of this genotype in the sample (results consistent with the $M A T$ genotype identified via the multiplex mating-type assay of Dyer et al. 2001b). It is feasible that these DNA extracts were obtained from mixed cultures containing both MAT genotypes. This mixed culture hypothesis could have been confirmed by single-sporing and retesting of the original isolates, but because the original isolates were not available, reisolation was not possible.

In planta application of new $O$. acuformis and $O$. yallundae species-specific LAMP assays. The new $O$. acuformis and O. yallundae species-specific LAMP assays were successfully applied to 17 test wheat samples with typical eyespot symptoms collected from the Czech Republic. In endpoint PCR testing, 14 tested positive only for $O$. yallundae, one only for $O$. acuformis, and

TABLE 4. Wheat stem samples from the Czech Republic screened for Oculimacula acuformis or $O$. yallundae with existing endpoint PCR assay and the new species-specific loop-mediated isothermal amplification (LAMP) assays

\begin{tabular}{|c|c|c|c|c|c|c|}
\hline \multirow[b]{2}{*}{$\begin{array}{l}\text { Sample } \\
\text { ID }\end{array}$} & \multirow[b]{2}{*}{ Sample origin ${ }^{\mathrm{a}}$} & \multirow[b]{2}{*}{$\begin{array}{l}\text { Eyespot symptoms } \\
\text { visible? }\end{array}$} & \multicolumn{2}{|c|}{$\begin{array}{l}\text { Species detected with the different molecular } \\
\text { assays }\end{array}$} & \multicolumn{2}{|c|}{$\begin{array}{c}\text { Raw data for new species-specific LAMP assays (time } \\
\text { to positive result) }{ }^{\mathrm{b}}\end{array}$} \\
\hline & & & Endpoint $\mathrm{PCR}^{\mathrm{c}}$ & LAMP & $\begin{array}{l}\text { O. acuformis-specific } \\
\text { LAMP assay }\end{array}$ & $\begin{array}{l}\text { O. yallundae-specific } \\
\text { LAMP assay }\end{array}$ \\
\hline 18 & Prague, CZ & Yes & O. yallundae & O. acuformis $+O$. yallundae & $+(11.15 \mathrm{~min})$ & $+(7.94 \mathrm{~min})$ \\
\hline 19 & Prague, CZ & Yes & O. yallundae & $O$. acuformis $+O$. yallundae & $+(11.90 \mathrm{~min})$ & $+(7.95 \mathrm{~min})$ \\
\hline 20 & Prague, CZ & Yes & O. yallundae & $O$. acuformis $+O$. yallundae & $+(11.76 \mathrm{~min})$ & $+(7.96 \mathrm{~min})$ \\
\hline 21 & Prague, $\mathrm{CZ}$ & Yes & O. yallundae & O. acuformis $+O$. yallundae & $+(14.24 \mathrm{~min})$ & $+(7.18 \mathrm{~min})$ \\
\hline 22 & Prague, $\mathrm{CZ}$ & Yes & O. yallundae & $O$. acuformis $+O$. yallundae & $+(17.11 \mathrm{~min})$ & $+(8.79 \mathrm{~min})$ \\
\hline 23 & Prague, $\mathrm{CZ}$ & Yes & - & O. yallundae & - & $+(9.19 \mathrm{~min})$ \\
\hline $24^{\mathrm{d}}$ & Prague, $\mathrm{CZ}$ & No & - & - & - & - \\
\hline $25^{\mathrm{d}}$ & Prague, $\mathrm{CZ}$ & No & - & - & - & - \\
\hline 26 & Prague, $\mathrm{CZ}$ & Yes & O. acuformis & O. acuformis $+O$. yallundae & $+(11.76 \mathrm{~min})$ & $+(10.49 \mathrm{~min})$ \\
\hline 28 & Kroměříž, CZ & Yes & O. yallundae & O. acuformis $+O$. yallundae & $+(10.47 \mathrm{~min})$ & $+(6.72 \mathrm{~min})$ \\
\hline 29 & Kroměříž, CZ & Yes & O. yallundae & O. yallundae & - & $+(6.56 \mathrm{~min})$ \\
\hline 30 & Kroměříž, CZ & Yes & O. yallundae & O. yallundae & - & $+(6.82 \mathrm{~min})$ \\
\hline 31 & Kroměříž, CZ & Yes & O. yallundae & O. acuformis $+O$. yallundae & $+(11.80 \mathrm{~min})$ & $+(6.84 \mathrm{~min})$ \\
\hline 32 & Kroměříž, CZ & Yes & O. yallundae & O. acuformis $+O$. yallundae & $+(20.01 \mathrm{~min})$ & $+(6.81 \mathrm{~min})$ \\
\hline 33 & Kroměříž, CZ & Yes & O. yallundae & O. yallundae & - & $+(8.18 \mathrm{~min})$ \\
\hline 34 & Kroměříž, CZ & Yes & O. yallundae & $O$. acuformis $+O$. yallundae & $+(11.83 \mathrm{~min})$ & $+(7.92 \mathrm{~min})$ \\
\hline 35 & Kroměříž, CZ & Yes & O. yallundae & O. yallundae & - & $+(6.70 \mathrm{~min})$ \\
\hline 36 & Kroměříž, CZ & Yes & O. yallundae & O. yallundae & - & $+(8.09 \mathrm{~min})$ \\
\hline 37 & Kroměříž, CZ & Yes & - & O. acuformis & $+(9.94 \mathrm{~min})$ & - \\
\hline $38^{\mathrm{d}}$ & United Kingdom & No & - & - & - & - \\
\hline $39^{d}$ & United Kingdom & No & - & - & - & - \\
\hline
\end{tabular}

a CZ, Czech Republic.

$\mathrm{b}+$, positive; -, negative; and nd, no data.

${ }^{c}$ Endpoint PCR assay of Walsh et al. (2005).

d Negative control samples: 24 and 25 were wheat stems with no eyespot lesions; 38 and 39 were Brassica napus (oilseed rape) leaves and stems, which is not a known host of Oculimacula spp. 
two tested negative for either species. By contrast, in LAMP testing all 17 wheat samples gave positive results for $O$. acuformi, $O$. yallundae, or both $O$. acuformis and $O$. yallundae, typically within $15 \mathrm{~min}$ (Table 4). Indeed, LAMP testing revealed that several of the stem samples for which only $O$. acuformis or $O$. yallundae had been detected by endpoint PCR actually contained both species. The four additional control wheat (24 and 25) and oilseed rape (38 and 39) stem samples that visually appeared healthy (i.e., no eyespot disease symptoms) gave no signal for $O$. acuformis or O. yallundae in either PCR- or LAMP-based testing.

Ascospore discharge and dispersal in the field. Observations during the wheat growing season confirmed the presence of eyespot disease symptoms at both plots at the RRes and Woburn Farm sites but with notably greater severity (a disease index score of $43 \%$ ) at the RRes site. This difference was reflected in a far higher number of apothecia characteristic of $O$. yallundae being found on stubble after harvest at the Little Knott Field plot at RRes Farm (average of 9.7 mature apothecia per stem at Little Knott vs. 1.0 at the Woburn Farm site) (Supplementary Fig. S2), and therefore spore trap efforts were conducted exclusively at the RRes Farm site.

Microscopic examinations of spore trap samples from within the inoculated plot at the Little Knott Field site revealed the presence of spores with the characteristic lozenge, round-ended morphology and size ( 7 to $11 \mu \mathrm{m}$ length), and they were 0 to 1 septate, typical of ascospores of $O$. yallundae (Andrade 2005; Wallwork and Spooner 1988) (Supplementary Fig. S3). This differed from the elongate asexual conidia of $O$. yallundae, which are 35 to $80 \mu \mathrm{m}$ in length (Nirenberg 1981), which were not observed. Subsequent examination of spore trap samples from downwind of the plot also revealed the presence of putative ascospores of $O$. yallundae, although more rarely than from within the plot. Again, there was no evidence for the presence of conidia of $O$. yallundae.

When DNA was extracted from known numbers of ascospores of O. yallundae on sections of Melinex tape and amplified via the newly developed species and mating-type specific PCR diagnostic assay, it was possible to detect a minimum threshold of 100 ascospores of $O$. yallundae. The assay resulted in production of the predicted 700 or 900 bp amplicons (data not shown). In follow-up work DNA was extracted from 14 days of daily spore tape samples obtained from the Little Knott Field plot or $2 \mathrm{~m}$ downwind of the plot. Molecular analysis via the species and mating-type specific multiplex PCR diagnostic assay from samples within the Little Knott plot revealed the presence of both MAT1-1 (900 bp) and MAT1-2 (700 bp) amplicons of $O$. yallundae on 4 of the 14 sampling

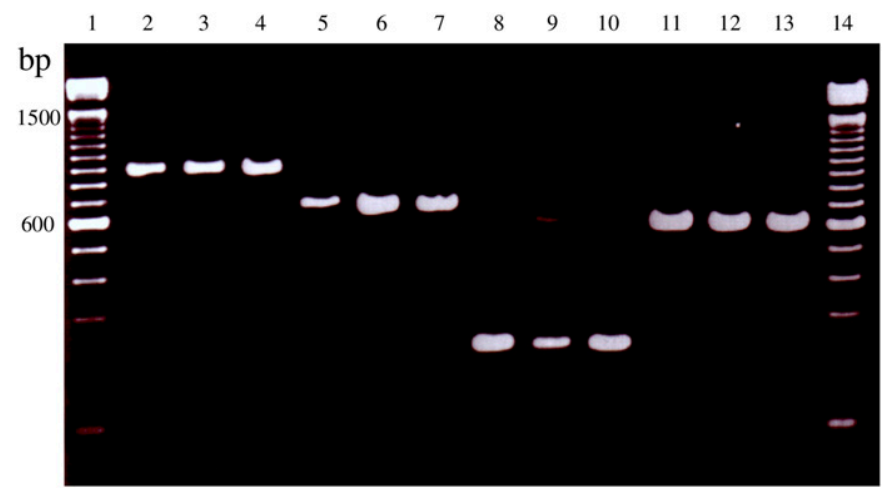

Fig. 2. Ethidium bromide-stained agarose gel image of representative results of the species and mating-type-specific multiplex PCR for Oculimacula acuformis and $O$. yallundae. Lanes 1 and 14, 100-bp ladder; lanes 2 to 4, $O$. yallundae MAT1-1 isolates (22-433, 22-453, and 22-417); lanes 5 to 7, $O$. yallundae MAT1-2 isolates (22-432, 22-434, and 37-18-6); lanes 8 to $10, O$. acuformis MAT1-1 isolates (38-30-20, 22-486, and 38-30-01); lanes 11 to 13, O. acuformis MAT1-2 isolates (38-30-9, 22-488, and 38-30-2). Note the presence of diagnostic amplicons of different sizes (900, 700, 250, and $600 \mathrm{bp}$, respectively). days; MAT1-1 alone was found on four days, whereas MAT1-2 alone was found on only one of the sampling days (Fig. 4A). This was consistent with the discharge of ascospores within the plot and subsequent observed trapping on the Melinex tape. No amplification products were obtained from samples from the remaining days. The same molecular analysis using the multiplex PCR diagnostic assay from samples downwind of the Little Knott plot again revealed the presence of characteristic amplicons of $O$. yallundae. MAT1-1 PCR products alone were found on 3 of the 14 sampling days, whereas MAT1-2 products were found alone on 2 days, and on only 1 day were both MAT1-1 and MAT1-2 products detected (Fig. 4B). Results were consistent with the discharge and subsequent airborne dispersal of ascospores from the inoculated plot and subsequent observed trapping on the Melinex tape. No amplification products were obtained from samples from the remaining days, suggesting that variation in weather conditions might have influenced daily ascospore release.

\section{DISCUSSION}

The present study describes the development of both a multiplex PCR diagnostic for simultaneous species and mating-type identification of $O$. acuformis and $O$. yallundae and also development of first LAMP assays for rapid species-specific and mating-type discrimination of $O$. acuformis and $O$. yallundae. Such assays will be of value given the practical challenge of diagnosing cereal eyespot disease in the field and will enable confirmation of which Oculimacula species is present; confirmation of eyespot identity is needed because other cereal stem-base pathogens can cause very similar visible disease symptoms (Nicholson et al. 1997). In addition, the present study provides the first evidence we are aware of for the dispersal of
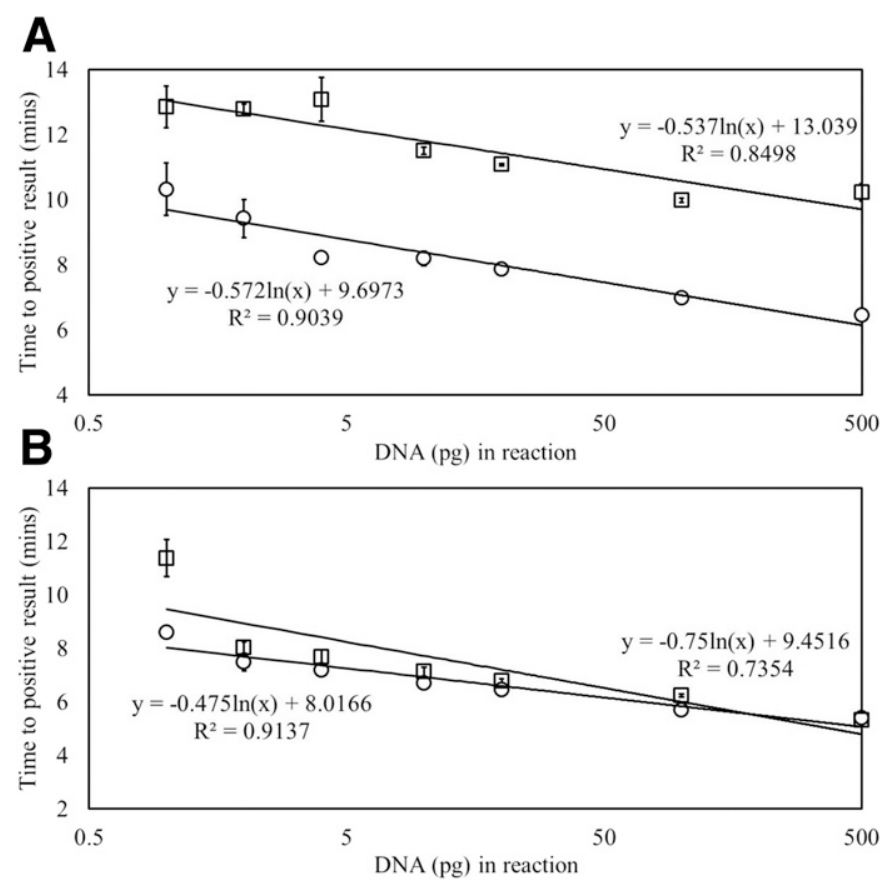

Fig. 3. Sensitivity of the Oculimacula acuformis and $O$. yallundae species and mating-type-specific loop-mediated isothermal amplification (LAMP) assays evaluated by screening against different amounts of pathogen DNA. A, Screening of $O$. yallundae DNA (isolate 22-491, circles) against the $O$. yallundae species-specific LAMP primer set, and screening of $O$. acuformis DNA (isolate 22-493, squares) against the $O$. acuformis-specific LAMP primer set. B, Screening of $O$. yallundae MAT1-1 DNA (isolate 22-491, circles) against the $O$. acuformis + O. yallundae MAT1-1-specific LAMP primer set, and $O$. yallundae MAT1-2 DNA (isolate 22-495, squares) against the O. acuformis + $O$. yallundae MAT1-2-specific primer set. Data points shown are the means of 2 technical replicates, and error bars are \pm SEM. 
ascospores of Oculimacula species in a field setting, an observation significant for elucidating the role of the sexual cycle in the generation of genetic diversity and development of eyespot epidemics.

The new multiplex PCR diagnostic for simultaneous species and mating-type identification of $O$. acuformis and $O$. yallundae represents an improvement on the previously described multiplex PCR diagnostic of Dyer et al. (2001b), which did not determine the mating type of isolates of Oculimacula species in a species-specific manner. Testing of the new multiplex PCR with DNA from $>40$ isolates of $O$. acuformis and $O$. yallundae from various locations in Europe, New Zealand, and the United States consistently gave a single amplicon revealing both species and mating-type identity of isolates. By contrast, no products were obtained with DNA templates from other fungal pathogens associated with cereal stem-base disease, showing the specificity and robustness of the test. These findings suggest that this diagnostic assay will be of value for researchers and agronomists who are currently using classic PCR approaches and who need to determine Oculimacula species identity for reasons including choice of fungicide treatment (Bateman and Jenkyn 2001). By also providing details of the mating-type identity of isolates, the diagnostic will give insights into the occurrence of sexual reproduction in populations of the pathogens at field locations. Sexual recombination can play an important role in the evolution of traits such as pathogenicity and resistance to fungicides (Dyer et al. 2000; McDonald and Linde 2002). Thus, it represents an improvement over other morphological and molecular diagnostics, which only differentiate between $O$. acuformis and $O$. yallundae (see Hollins et al. 1985 and Nicholson et al. 1997).

The specificity of the new $O$. acuformis- and $O$. yallundaespecific LAMP diagnostic was confirmed by screening against DNA from 20 isolates of $O$. acuformis and $O$. yallundae from various locations in Europe and New Zealand. Both the $O$. acuformis and $O$. yallundae species-specific LAMP assays were found to be highly sensitive (with detection of as little as $1 \mathrm{pg}$ of Oculimacula DNA), operated at a single constant temperature $\left(65^{\circ} \mathrm{C}\right)$, and were extremely fast (species identity confirmed in as
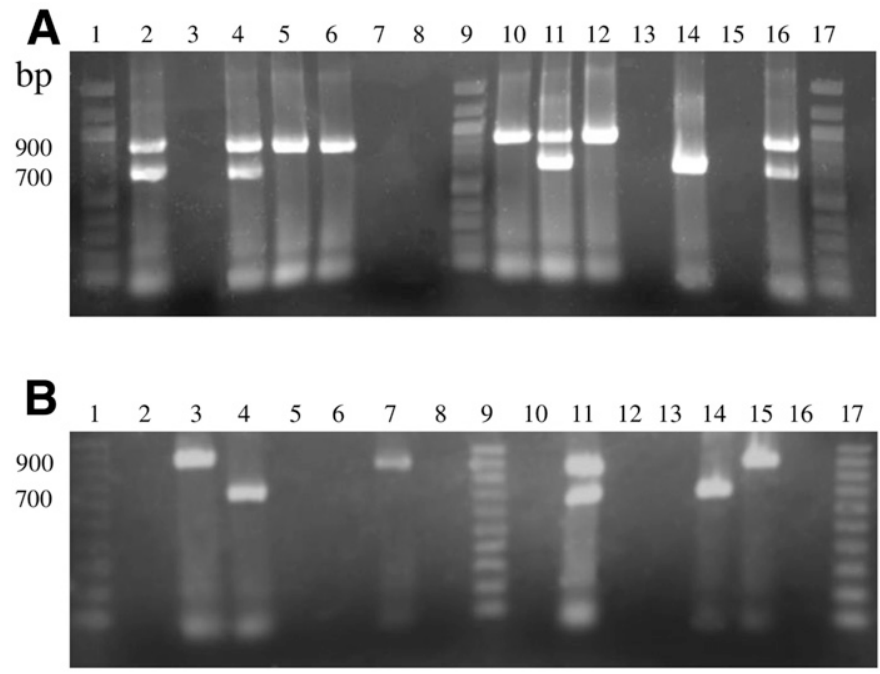

Fig. 4. Ethidium bromide-stained agarose gel images of PCR amplification via the species- and mating-type-specific multiplex diagnostic for Oculimacula yallundae on DNA extracted from various Melinex tape samples. A, Amplicons obtained from daily sampling from within the Little Knott Field plot at RRes Farm: lanes 1, 9, and 17, 100-bp ladder; lanes 2 to 8, samples from days 1 to 7 of spore trapping; lanes 10 to 16 , samples from days 8 to 14 of spore trapping. B, Amplicons obtained from daily sampling from $2 \mathrm{~m}$ downwind of the Little Knott Field plot at RRes Farm: lanes 1, 9, and 17, 100-bp ladder; lanes 2 to 8 , samples from days 1 to 7 of spore trapping; lanes 10 to 16 , samples from days 8 to 14 of spore trapping. Note that the 900 -bp product corresponds to an $O$. yallundae MAT1-1 isolate and that $700 \mathrm{bp}$ corresponds to an $O$. yallundae MAT1-2 isolate. little as 6 min) compared with the classic PCR multiplex diagnostic, illustrating a major advantage of the LAMP assays. Importantly, neither LAMP assay tested positive for the closely related P. brassicae or Rhynchosporium spp. (Goodwin 2002), nor for a broad range of other plant pathogenic ascomycetes.

The LAMP assays were also successfully applied in pilot studies to DNA extracted from wheat stem samples from two sites in the Czech Republic, enabling rapid (typically within $15 \mathrm{~min}$, rarely $20 \mathrm{~min}$ ) identification of the Oculimacula species present, bypassing the need for time-consuming and laborious fungal isolation and culturing. In comparison with the multiplex PCR assay developed by Walsh et al. (2005), the LAMP assays appeared more robust in detecting whether one or both species were present in the field samples. Quick and unambiguous species identification can improve eyespot control (Bateman and Jenkyn 2001). By contrast, the new multiplex PCR diagnostic has not yet been tested with DNA extracted directly from plant samples. The new LAMP assays were also less laborious (e.g., needing only the use of a portable heat block, with results immediately available) than the multiplex PCR and previously available PCR and morphological assays for discriminating the species (Hollins et al. 1985; Nicholson et al. 1997). Other advantages of the LAMP assays are that they may be used to quickly screen large numbers of Oculimacula field isolates, such as those obtained in long-term studies investigating changes in $O$. acuformis and O. yallundae abundance over time (Douhan et al. 2002a; Parnell et al. 2008) and might be applied to explore the presence of Oculimacula species inoculum in air environmental samples. The new Oculimacula species-specific LAMP assays will also complement LAMP diagnostics already available for other damaging wheat pathogens, including Fusarium graminearum (Niessen and Vogel 2010), Puccinia striiformis f. sp. tritici (Aggarwal et al. 2017), and Magnaporthe oryzae Triticum pathotype (Yasuhara-Bell et al. 2018). More widely, LAMP assays have been developed for other economically important fungal phytopathogens, including Leptosphaeria biglobosa or Leptosphaeria maculans on oilseed rape (Brassica napus), Fusarium fujikuroi or Fusarium proliferatum on rice, and Pyrenopeziza brassicae on brassicas (Jędryczka et al. 2013; King et al. 2018; Rong et al. 2018).

One additional output from the study was the development of LAMP assays for rapid amplification ( $<12 \mathrm{~min})$ and identification of either MAT1-1 or MAT1-2 isolates of both O. acuformis and $O$. yallundae. The assays appeared robust, being successfully applied to 20 isolates of $O$. acuformis and $O$. yallundae of known mating type from a broad geographic range of locations. Both LAMP assays appeared specific only to Oculimacula spp., with no amplification of closely related P. brassicae or Rhynchosporium spp. of known MAT1-1 or MAT1-2 identity. Thus, these mating-type LAMP assays offer advantages in time and efficiency over the new classic PCR multiplex diagnostic developed in the present study and the previous MAT diagnostic of Dyer et al. (2001b). This is thought to be only the second use of LAMP technology in fungal matingtype determination, following the development of previous LAMP assays for MAT identification in the opportunistic human pathogen Aspergillus fumigatus (King et al. 2019). As with the new PCR multiplex diagnostic, the mating-type LAMP assays will provide valuable diagnostic tools to indirectly investigate the equilibrium status of mating types in Oculimacula field populations, and it is anticipated that similar MAT-specific LAMP assays can be developed for related P. brassicae and Rhynchosporium spp. (Foster et al. 2002; Goodwin 2002; King et al. 2015).

In the final part of the study, the new multiplex PCR diagnostic was used in a pilot study to investigate the possible wind dispersal of ascospores of $O$. yallundae both within a plot showing eyespot disease and beyond the border of the plot. Asexually produced conidia spread over short distances by rain splash (Fitt and Bainbridge 1983) are currently considered to be the main source of inoculum for Oculimacula spp., and the role of ascospores has remained largely unclear (Dyer et al. 1994a; Lucas et al. 2000). Spore 
trapping was conducted during the period of the growing season when apothecia are thought to actively discharge ascospores (Dyer et al. 1994a, 2001a). The subsequent detection of DNA of $O$. yallundae in spore traps downwind of the plots with diseased wheat provides evidence for the proposed role for ascospores in medium- and longrange dispersal of eyespot disease. Also, the fact that the molecular diagnostic required a minimum of about 100 spores to generate a band indicates that a high number of ascospores were being dispersed. Indeed, further investigation by random amplification of polymorphic DNA PCR fingerprinting showed that the Oculimacula DNA detected in the spore traps was consistent with that produced by recombination of the parental strains used to inoculate the site (Eyres 2007). DNA present on the spore tapes could have arisen from conidia of $O$. yallundae. However, this is unlikely because there was no evidence of conidia on the spore tapes that were observed by microscope, unlike the putative ascospores observed by microscopy, and the distance and height of spore trapping were beyond that normally associated with splash-dispersed conidia (Fitt and Bainbridge 1983). The infectivity of ascospores of $O$. yallundae has already been demonstrated (Daniels et al. 1995), and Dyer and Lucas (1995) found that apothecia of Oculimacula spp. were present on $\leq 32 \%$ of stubble stems sampled at 45 sites in England (although mainly on $<3 \%$ of stems), indicating that ascospores can be an important source of airborne and genetically diverse fungal inoculum. Elsewhere, there are parallel examples from fungal plant pathogens including $P$. brassicae, where conidia are splash dispersed over short distances compared with longer-distance dispersal of windborne ascospores, which are thought to initiate epidemics in oilseed rape crops (Gilles et al. 2000).

In conclusion, we describe the development of both classic PCRbased multiplex and LAMP assays for the diagnosis of species and mating-type identity in $O$. acuformis and $O$. yallundae. The study has also shown how these methods can be applied in the field to study processes such as spore dispersal, with the first evidence provided of ascospore discharge by $O$. yallundae in the field. Each diagnostic has its own advantages, such as the simultaneous determination of species and mating-type identity by the multiplex PCR versus the speed and field applicability of the LAMP assays. Therefore, the choice of which to use depends on the application and the experience of their end users.

\section{ACKNOWLEDGMENTS}

We thank Paul Nicholson (John Innes Centre) for donation of fungal cultures.

\section{LITERATURE CITED}

Aggarwal, R., Sharma, S., Manjunatha, C., Gupta, S., and Singh, V. K. 2017. Development and validation of loop mediated isothermal amplification based detection assay for Puccinia striiformis f. sp. tritici causing stripe rust of wheat. Australas. Plant Pathol. 46:577-583.

Andrade, O. 2005. Identification of Tapesia yallundae, the causal agent of eyespot in wheat in southern Chile. Agric. Téc. (Chillán) 65:306-311.

Bateman, G., and Jenkyn, J. 2001. Biology and control of stem-base diseases of cereals in the UK. Pestic. Outlook 12:103-106.

Bierman, S. M., Fitt, B. D. L., van den Bosch, F., Bateman, G. L., Jenkyn, J. F., and Welham, S. J. 2002. Changes in populations of the eyespot fungi Tapesia yallundae and T. acuformis under different fungicide regimes in successive crops of winter wheat, 1984-2000. Plant Pathol. 51: 191-201.

Burt, C., Hollins, T. W., Powell, N., and Nicholson, P. 2010. Differential seedling resistance to the eyespot pathogens, Oculimacula yallundae and Oculimacula acuformis, conferred by Pch2 in wheat and among accessions of Triticum monococcum. Plant Pathol. 59:819-828.

Calderon, C., Ward, E., Freeman, J., and McCartney, A. 2002. Detection of airborne fungal spores sampled by rotating-arm and Hirst-type spore traps using polymerase chain reaction assays. J. Aerosol Sci. 33:283-296.

Crous, P. W., Groenewald, J. Z. E., and Gams, W. 2003. Eyespot of cereals revisited: ITS phylogeny reveals new species relationships. Eur. J. Plant Pathol. 109:841-850.
Daniels, A., Papaikonomou, M., Dyer, P. S., and Lucas, J. A. 1995. Infection of wheat seedlings by ascospores of Tapesia yallundae: morphology of the infection process and evidence for recombination. Phytopathology 85: 918-927.

Douhan, G. W., Murray, T. D., and Dyer, P. S. 2002a. Species and mating-type distribution of Tapesia yallundae and T. acuformis and occurrence of apothecia in the US Pacific Northwest. Phytopathology 92:703-709.

Douhan, G. W., Murray, T. D., and Dyer, P. S. 2003. Population genetic structure of Tapesia acuformis in Washington State. Phytopathology 93:650-656.

Douhan, G. W., Peever, T. L., and Murray, T. D. 2002b. Multilocus population structure of Tapesia yallundae in Washington State. Mol. Ecol. 11: 2229-2239.

Duan, Y. B., Yang, Y., Wang, J. X., Liu, C. C., He, L. L., and Zhou, M. G. 2015. Development and application of loop-mediated isothermal amplification for detecting the highly benzimidazole-resistant isolates in Sclerotinia sclerotiorum. Sci. Rep. 5:17278.

Dyer, P. S., Bateman, G. L., Lucas, J. A., and Peberdy, J. F. 1994a. Seasonal development of apothecia of the cereal eyespot pathogen Tapesia yallundae on straw stubble in the UK. Ann. Appl. Biol. 125:489-500.

Dyer, P. S., Bateman, G. L., and Wood, H. M. 2001a. Development of apothecia of the eyespot pathogen Tapesia on cereal crop stubble residue in England. Plant Pathol. 50:356-362.

Dyer, P. S., and Bradshaw, R. E. 2002. First report of apothecia of Tapesia yallundae occurring on the wild grass Holcus lanatus (Yorkshire Fog) in New Zealand. Plant Pathol. 51:806.

Dyer, P. S., Furneaux, P. A., Douhan, G., and Murray, T. D. 2001b. A multiplex PCR test for determination of mating type applied to the plant pathogens Tapesia yallundae and Tapesia acuformis. Fungal Genet. Biol. 33:173-180.

Dyer, P. S., Hansen, J., Delaney, A., and Lucas, J. A. 2000. Genetic control of resistance to the sterol $14 \alpha$-demethylase inhibitor fungicide prochloraz in the cereal eyespot pathogen Tapesia yallundae. Appl. Environ. Microbiol. 66:4599-4604.

Dyer, P. S., Inderbitzin, P., and Debuchy, R. 2016. Mating-type structure, function, regulation and evolution in the Pezizomycotina. Pages 351-385 in: Growth, Differentiation and Sexuality, The Mycota I, 3rd ed., J. Wendland, ed. Springer International Publishing, Cham, Switzerland.

Dyer, P. S., and Lucas, J. A. 1995. Incidence of apothecia of Tapesia yallundae at set-aside sites in England and sensitivity of the ascospore offspring to the fungicides benomyl and prochloraz. Plant Pathol. 44:796-804.

Dyer, P. S., Nicholson, P., Lucas, J. A., and Peberdy, J. F. 1996. Tapesia acuformis as a causal agent of eyespot disease of cereals and evidence for a heterothallic mating system using molecular markers. Mycol. Res. 100: 1219-1226.

Dyer, P. S., Nicholson, P., Rezanoor, H. N., Lucas, J. A., and Peberdy, J. F. 1993. Two-allele heterothallism in Tapesia yallundae, the teleomorph of the cereal eyespot pathogen Pseudocercosporella herpotrichoides. Physiol. Mol. Plant Pathol. 43:403-414.

Dyer, P. S., Papaikonomou, M., Lucas, J. A., and Peberdy, J. F. 1994b. Isolation of R-type progeny of Tapesia yallundae from apothecia on wheat stubble in England. Plant Pathol. 43:1039-1044.

Eyres, G. J. 2007. Evolution and applications of mating-type genes of pezizomycete fungi. Ph.D. thesis, University of Nottingham, UK.

Fitt, B. D. L. 1992. Eyespot of cereals. Pages 336-354 in: Plant Diseases of International Importance. Volume I. Diseases of Cereals and Pulses. Singh U. S., A. N. Mukhopadhyay, J. H. Kumar, and S. Chaube, eds. Prentice Hall, Englewood Cliffs, NJ.

Fitt, B. D. L., and Bainbridge, A. 1983. Dispersal of Pseudocercosporella herpotrichoides spores from infected wheat straw. J. Phytopathol. 106: 214-225.

Foster, S. J., Ashby, A. M., and Fitt, B. D. L. 2002. Improved PCR-based assays for pre-symptomatic diagnosis of light leaf spot and determination of mating type of Pyrenopeziza brassicae on winter oilseed rape. Eur. J. Plant Pathol. 108:379-383.

Gilles, T., Evans, N., Fitt, B. D. L., and Jeger, M. J. 2000. Epidemiology in relation to methods for forecasting light leaf spot (Pyrenopeziza brassicae) severity on winter oilseed rape (Brassica napus) in the UK. Eur. J. Plant Pathol. 106:593-605.

Goodwin, S. B. 2002. The barley scald pathogen Rhynchosporium secalis is closely related to the discomycetes Tapesia and Pyrenopeziza. Mycol. Res. 106:645-654.

Goulds, A., and Fitt, B. D. L. 1991. The development of eyespot on stems of winter wheat and winter barley in crops inoculated with W-type or R-type isolates of Pseudocercosporella herpotrichoides. Z. Pflanzenk. Pflanzen. 98:490-502.

Hollins, T. W., Scott, P. R., and Paine, J. R. 1985. Morphology, benomyl resistance and pathogenicity to wheat and rye of isolates of Pseudocercosporella herpotrichoides. Plant Pathol. 34:369-379.

Jẹdryczka, M., Burzynski, A., Brachaczek, A., Langwinski, W., Song, P., and Kaczmarek, J. 2013. Loop-mediated isothermal amplification as a good tool 
to study changing Leptosphaeria populations in oilseed rape plants and air samples. Acta Agrobot. 66:93-100.

King, K. M., Hawkins, N. J., Atkins, S., Dyer, P. S., West, J. S., and Fraaije, B. A. 2019. First application of loop-mediated isothermal amplification (LAMP) assays for rapid identification of mating type in the heterothallic fungus Aspergillus fumigatus. Mycoses 62:812-817.

King, K. M., Krivova, V., Canning, G. G. M., Hawkins, N. J., Perryman, S. A. M., Dyer, P. S., Fraaije, B. A., and West, J. S. 2018. Loop-mediated isothermal amplification (LAMP) assays for rapid detection of Pyrenopeziza brassicae (light leaf spot of brassicas). Plant Pathol. 67:167-174.

King, K. M., West, J. S., Fitt, B. D. L., and Dyer, P. S. 2015. Differences in MAT gene distribution and expression between Rhynchosporium species on grasses. Plant Pathol. 64:344-354.

Lacey, M. E., and West, J. S., eds. 2006. The Air Spora. Springer, Cham, The Netherlands.

Leroux, P., and Gredt, M. 1997. Evolution of fungicide resistance in the cereal eyespot fungi Tapesia yallundae and Tapesia acuformis in France. Pestic. Sci. 51:321-327.

Lucas, J. A., Dyer, P. S., and Murray, T. D. 2000. Pathogenicity, hostspecificity, and population biology of Tapesia spp., causal agents of eyespot disease of cereals. Adv. Bot. Res. 33:225-258.

Lucas, J. A., Hawkins, N. J., and Fraaije, B. A. 2015. The evolution of fungicide resistance. Adv. Appl. Microbiol. 90:29-92.

McDonald, B. A., and Linde, C. C. 2002. Pathogen population genetics, evolutionary potential, and durable resistance. Annu. Rev. Phytopathol. 40:349-379.

Nicholson, P., Rezanoor, H. N., Simpson, D. R., and Joyce, D. 1997. Differentiation and quantification of the cereal eyespot fungi Tapesia yallundae and Tapesia acuformis using a PCR assay. Plant Pathol. 46:842-856.

Niessen, L., and Vogel, R. F. 2010. Detection of Fusarium graminearum DNA using a loop-mediated isothermal amplification (LAMP) assay. Int. J. Food Microbiol. 140:183-191.

Nirenberg, H. I. 1981. Differentiation of Pseudocercosporella strains causing foot rot disease of cereals. Morphology. Z. Pflanzenk. Pflanzen. 88:241-248.
Notomi, T., Okayama, H., Masubuchi, H., Yonekawa, T., Watanabe, K., Amino, N., and Hase, T. 2000. Loop-mediated isothermal amplification of DNA. Nucleic Acids Res. 28:e63.

Parnell, S., Gilligan, C. A., Lucas, J. A., Bock, C. H., and van den Bosch, F. 2008. Changes in fungicide sensitivity and relative species abundance in Oculimacula yallundae and $O$. acuformis populations (eyespot disease of cereals) in Western Europe. Plant Pathol. 57:509-517.

Ray, R. V., Crook, M. J., Jenkinson, P., and Edwards, S. G. 2006. Effect of eyespot caused by Oculimacula yallundae and $O$. acuformis, assessed visually and by competitive PCR, on stem strength associated with lodging resistance and yield of winter wheat. J. Exp. Bot. 57:2249-2257.

Rong, Z., Yuan, Y., Ye, W., Wang, X., and Zheng, X. 2018. Rapid diagnosis of rice bakanae caused by Fusarium fujikuroi and $F$. proliferatum using loopmediated isothermal amplification assays. J. Phytopathol. 166:283-290.

Scott, P. R., and Hollins, T. W. 1974. Effects of eyespot on the yield of winter wheat. Ann. Appl. Biol. 78:269-279.

Turner, A. S., Nicholson, P., Edwards, S. G., Bateman, G. L., Morgan, L. W., Parry, D. W., Marshall, J., and Nuttall, M. 2001. Evaluation of diagnostic and quantitative PCR for the identification and severity assessment of eyespot and sharp eyespot in winter wheat. Plant Pathol. 50:463-469.

Wallwork, H., and Spooner, B. 1988. Tapesia yallundae: the teleomorph of Pseudocercosporella herpotrichoides. Trans. Br. Mycol. Soc. 91:703-705.

Walsh, K., Korimbocus, J., Boonham, N., Jennings, P., and Hims, M. 2005. Using real-time PCR to discriminate and quantify the closely related wheat pathogens Oculimacula yallundae and Oculimacula acuformis. J. Phytopathol. 153:715-721.

Wong, Y.-P., Othman, S., Lau, Y.-L., Radu, S., and Chee, H.-Y. 2018. Loopmediated isothermal amplification (LAMP): a versatile technique for detection of micro-organisms. J. Appl. Microbiol. 124:626-643.

Yasuhara-Bell, J., Pedley, K. F., Farman, M., Valent, B., and Stack, J. P. 2018. Specific detection of the wheat blast pathogen (Magnaporthe oryzae Triticum) by loop-mediated isothermal amplification. Plant Dis. 102: 2550-2559.

This article was modified on 18 Oct 2021. 


\section{ERRATUM / Volume 111, Number 3, 2021 / PHYTO-04-20-0116-R}

In the article "Novel Multiplex and Loop-Mediated Isothermal Amplification Assays for Rapid Species and Mating-Type Identification of Oculimacula acuformis and O. yallundae (Causal Agents of Cereal Eyespot), and Application for Detection of Ascospore Dispersal and In Planta Use” by K. M. King, G. J. Eyres, J. S. West, C. Siraf, P. Matusinsky, J. Palicová, G. G. M. Canning, G. L. Bateman, B. A. Fraaije, and P. S. Dyer, in Table 3, the sequence of primer YM2 was incorrect. The correct sequence for primer YM2 is 5' -CACTCACAGATAGAATGATAGAG-3'.

(C) 2021 The American Phytopathological Society 